\title{
Impact of Evaluation of Different Irrigation Methods with Sensor System on Water Consumptive Use and Water Use Efficiency for Maize Yield
}

\author{
Thamer Thamer' ${ }^{1}$ Nadine Nassif², Ayad Almaeini' ${ }^{3}$ Nadhir Al-Ansari4* \\ ${ }^{1}$ Ecole Doctorale en Sciences et Technologie, Lebanese University, Rafic Hariri-Haddath, Lebanon \\ ${ }^{2}$ Faculty of Agronomy and Veterinary Sciences, Environment and Natural Resources Department, Lebanese University, \\ Dekwaneh, Beirut, Lebanon. \\ ${ }^{3}$ College of Agricultural Engineering Sciences, Baghdad University, Baghdad, Iraq \\ ${ }^{4}$ Department of Civil, Environmental and Natural Resources Engineering, Lule, University of Technology, Lule, Sweden \\ Email: alshibly.thamer@yahoo.com, Nadinenassif3@hotmail.com, d.ayadalmaini@gmail.com, *nadhir.alansari@ltu.se
}

How to cite this paper: Thamer, T., Nassif, N., Almaeini, A. and Al-Ansari, N. (2021) Impact of Evaluation of Different Irrigation Methods with Sensor System on Water Consumptive Use and Water Use Efficiency for Maize Yield. Journal of Water Resource and Protection, 13, 835-854.

https://doi.org/10.4236/jwarp.2021.1311045

Received: September 16, 2021

Accepted: November 19, 2021

Published: November 22, 2021

Copyright $\odot 2021$ by author(s) and Scientific Research Publishing Inc. This work is licensed under the Creative Commons Attribution International License (CC BY 4.0).

http://creativecommons.org/licenses/by/4.0/

\section{(c) (i) Open Access}

\begin{abstract}
The sensor system is one of the modern and important methods of irrigation management in arid and semi-arid areas, which is water as the limiting factor for crop production. The study was applied for 2016 and 2017 seasons out in Al-Yousifya, $15 \mathrm{~km}$ Southwest of Baghdad. A study was conducted to evaluate coefficient uniformity, uniformity distribution and application efficiency for furrow, surface drip and subsurface drip irrigation methods and it was $(98,97$ and 89)\% and (97, 96 and 88)\% for 2016 and 2017 seasons; respectively. And control the volumetric moisture content according to the rhizosphere depth for depths of 10, 20 and $30 \mathrm{~cm}$ by means of the sensor system. The results indicated that the height consumptive water use of furrow 707.91 and 689.69 $\mathrm{mm} \cdot$ season $^{-1}$ and the lowest for subsurface drip with emitter deep at $20 \mathrm{~cm}$ 313.93 and $293.50 \mathrm{~mm} \cdot$ season $^{-1}$ for 2016 and 2017 seasons; respectively. As well, the highest value of water use efficiency for subsurface in drip irrigation at a depth of $20 \mathrm{~cm}$, was 2.71 and $2.99 \mathrm{~kg} \cdot \mathrm{m}^{-3}$ and the lowest value for furrow irrigation was 1.12 and $1.20 \mathrm{~kg} \cdot \mathrm{m}^{-3}$ for the 2016 and 2017 seasons; respectively.
\end{abstract}

\section{Keywords}

Irrigation Methods, Application Efficiency, Water Consumptive Use, Water Use Efficiency, Maize 


\section{Introduction}

In recent years, farmers in developed countries have tended to use modern irrigation methods, and these methods have become widely used in arid and semi-arid areas where water is a limiting factor due to a water deficit. And those modern methods of irrigating crops can increase the soil's water-holding capacity, increase its permeability, reduce water lost to surface runoff and secure the water needs of plants [1]. Sub-surface drip irrigation is a method suitable for irrigation frequently in arid and semi-arid soils because it provides the best control of irrigation water and prepares the water near the rhizosphere of the plant if it is well managed and it is at a high level of control and leads to high crop productivity [2] and [3].

Irrigation efficiency is used to evaluate the application of the irrigation system and measure the efficiency of the water applied to the field in the root zone, which is used by the plant, and it indicates the suitability of the irrigation method used. And the irrigation efficiency was defined from [4] as the ratio of the water stored in the rhizosphere to the water applied to the field Amounts of water are greater than the soil's ability to hold, which causes water losses through deep permeation and runoff.

In general, irrigation efficiency for most well designed surface irrigation methods reaches $60 \%$, while in sprinkler irrigation it reaches $75 \%$, and it may reach $95 \%$ in surface and subsurface drip irrigation. Raising the irrigation efficiency is related to reducing water losses and increasing the amount of water stored in the rhizosphere, and this is related to achieving a balance between all the variables affecting the irrigation system (settlement and good management of the field and determining the appropriate slope and drainage and the appropriate field area) [5].

Also an appropriate amount of water sufficient to fill the rhizosphere with water to the limits of its field capacity greatly affects the efficiency of irrigation. Water must be added at a rate commensurate with the rate of infiltration into the soil. In general, the efficiency of irrigation decreases by increasing the amount of water applied during the irrigation. low irrigation (little amounts of water) are not enough to fill the rhizosphere, which makes the irrigation process not good, despite the high irrigation efficiency, and this may be reflected in production. The irrigation efficiency is affected by the type of soil, the irrigation method used, the amount of water applied, the porosity of the soil, and the time of irrigation [6] and [7]. Nowadays it has become necessary to use modern technologies in agriculture, management and scheduling of the irrigation process, the most important of these techniques is the sensor system that facilitates the monitoring and determination of the appropriate quantity and timing of irrigation, and that increase water productivity and crop productivity [8]. This study aims to evaluate irrigation methods using standards (application efficiency, uniformity distribution, coefficient uniformity and the lowest proportion of variance ) using several pressures, determine the best pressure in irrigation, control volumetric 
moisture content by using the sensor system, and determine the best irrigation method for water productivity and maize crop productivity in the central region of Iraq.

\section{Material and Methods}

The study was conducted in 2016 and 2017 at al-Yousifya, $15 \mathrm{~km}$ southwest of Baghdad-Iraq $\left(44^{\circ} 18^{\prime} 75^{\prime \prime} \mathrm{E}\right.$ and $33^{\circ} 07^{\prime} 84^{\prime \prime} \mathrm{N}, 34 \mathrm{~m}$ elevation above sea level Figure 1 on a silt clay (classified as Typic-Torriflovent). The climate in the middle Iraq is arid-semi arid. It is characterized by warm weather and minimal rainfall during the summer (the crop growing season). The weather data of Al-Yousifya Region is taken from Al-Raeed weather station which is located $5 \mathrm{~km}$ away from the experimental site. Typical measurements are illustrated in Figure 2.

\section{Soil Sampling Analysis}

The soil moisture release curve was estimated at, 33, 100, 500, 1000 and 1500 $\mathrm{kPa}$ for samples taken from depths of $(0-30 \mathrm{~cm})$ and $(30-60 \mathrm{~cm})$. Soil available water content was calculated from differences in moisture content at 33 and $1500 \mathrm{kPa}$ according to [9] Figure 3. Soil analyses were done for some physical and chemical properties of experimental soil at two depths $(0-30 \mathrm{~cm})$ and $(30$ $60 \mathrm{~cm}$ ) in 2016 and 2017 seasons Table 1.

\section{Experimental Design and Treatments}

The experiment was laid out according to a Completely Randomized Block

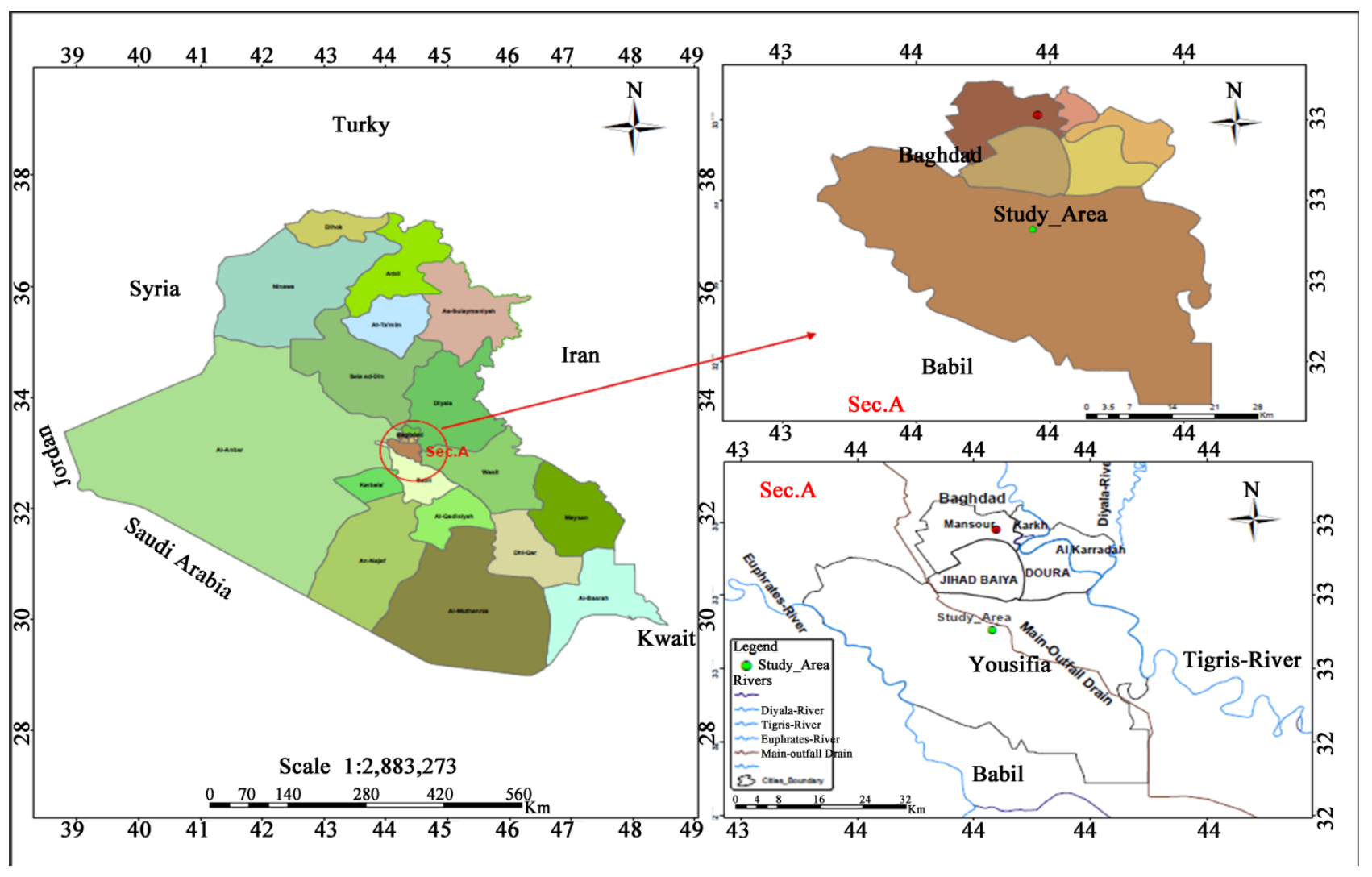

Figure 1. The location of the study area. 


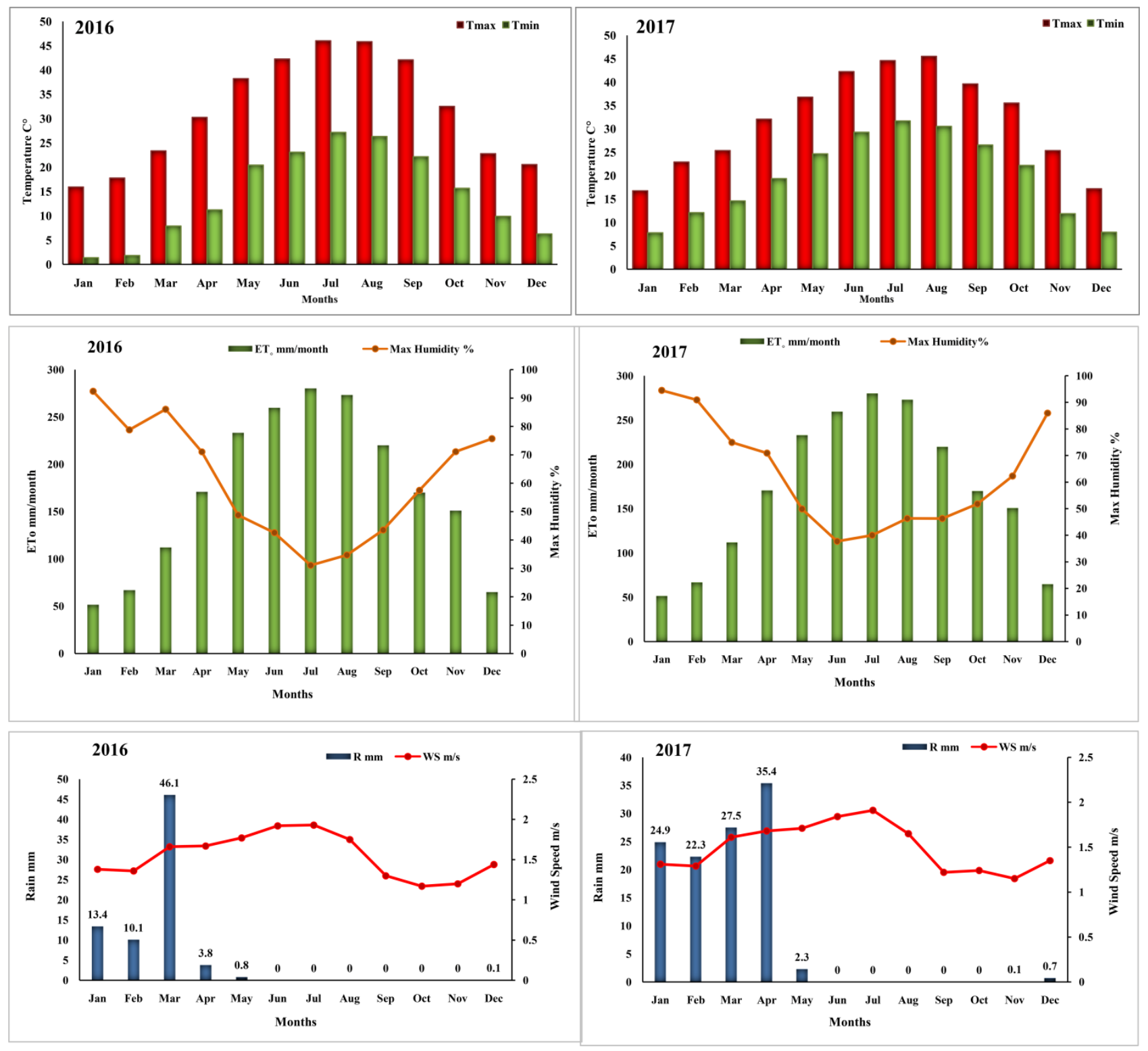

Figure 2. Some Climate data of the study area at 2016 and 2017 season.
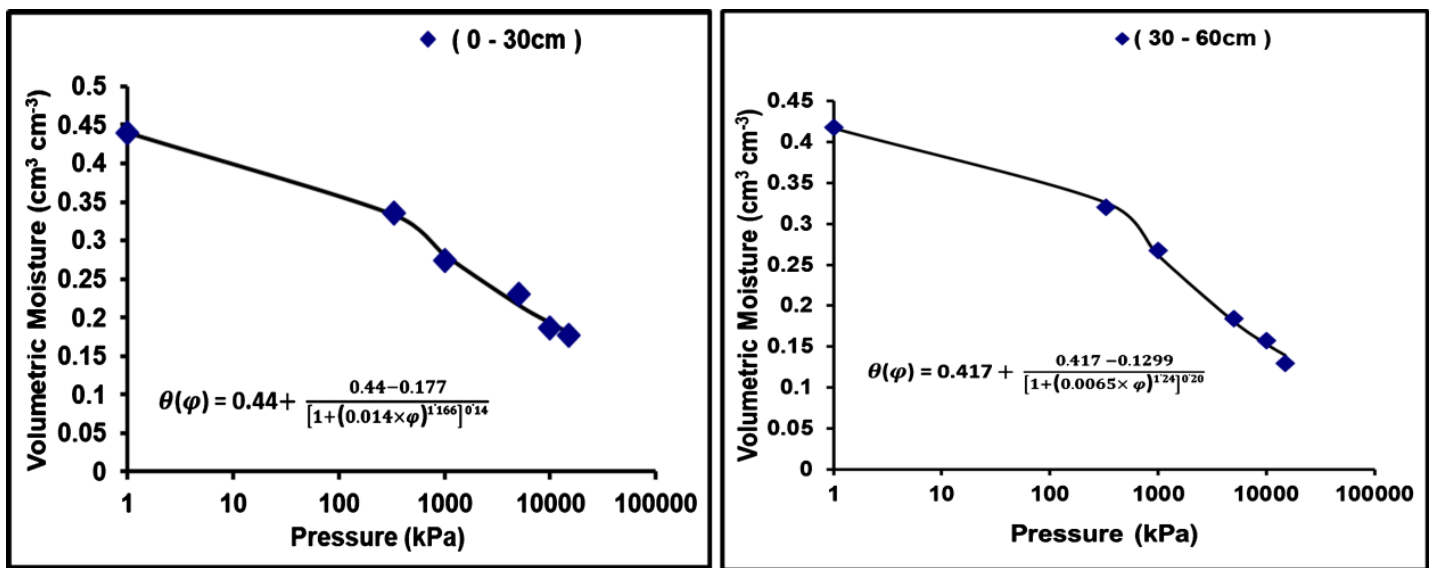

Figure 3. Soil moisture characteristic curve for $(0-30 \mathrm{~cm})$ and $(30-60 \mathrm{~cm})$ depths. 
Table 1. Chemical and physical properties of experimental soil.

\begin{tabular}{|c|c|c|c|c|c|}
\hline \multirow{2}{*}{\multicolumn{2}{|c|}{ Characteristic }} & \multirow{2}{*}{\multicolumn{2}{|c|}{$\begin{array}{c}2016 \\
\text { Soil depth }\end{array}$}} & \multirow{2}{*}{\multicolumn{2}{|c|}{$\begin{array}{c}2017 \\
\text { Soil depth }\end{array}$}} \\
\hline & & & & & \\
\hline & & $0-30 \mathrm{~cm}$ & $30-60 \mathrm{~cm}$ & $0-30 \mathrm{~cm}$ & $30-60 \mathrm{~cm}$ \\
\hline Sand & $\mathrm{g} \cdot \mathrm{kg}^{-1}$ & 120 & 115 & 119 & 114 \\
\hline Silt & & 620 & 648 & 623 & 653 \\
\hline Clay & & 260 & 237 & 258 & 233 \\
\hline \multicolumn{2}{|c|}{ Textural class } & \multicolumn{4}{|c|}{ Silty clay } \\
\hline $\mathrm{CaCO}_{3}$ & $\mathrm{~g} \cdot \mathrm{kg}^{-1}$ & 280 & 291 & 273 & 284 \\
\hline $\mathrm{OM}$ & & 4.51 & 2.37 & 5.71 & 3.12 \\
\hline CEC & $\mathrm{Cmol} \cdot \mathrm{kg}^{-1}$ & 23.31 & 20.45 & 23.43 & 19.87 \\
\hline Ec & $\mathrm{dsm}^{-1}$ & 3.2 & 2.7 & 3.1 & 2.8 \\
\hline $\mathrm{PH}$ & & 7.6 & 7.7 & 7.7 & 7.7 \\
\hline $\mathrm{N}$ & $\mathrm{Mg} \cdot \mathrm{kg}^{-1}$ & 23.42 & 19.32 & 22.64 & 18.21 \\
\hline $\mathrm{P}$ & & 12.21 & 11.72 & 13.37 & 11.17 \\
\hline $\mathrm{K}$ & & 121.32 & 117.47 & 135.65 & 129.55 \\
\hline $\mathrm{Ca}^{++}$ & $\mathrm{meq} \cdot \mathrm{L}^{-1}$ & 14.62 & 12.22 & 13.28 & 11.74 \\
\hline $\mathrm{Mg}^{++}$ & & 9.73 & 8.23 & 9.69 & 7.86 \\
\hline $\mathrm{Na}^{+}$ & & 4.41 & 5.18 & 5.17 & 6.23 \\
\hline $\mathrm{k}^{+}$ & & 3.24 & 2.07 & 2.91 & 2.21 \\
\hline $\mathrm{SO}_{4}^{2-}$ & & 14.61 & 13.25 & 13.57 & 12.61 \\
\hline $\mathrm{CO}_{3}$ & & \multicolumn{4}{|c|}{ Nil } \\
\hline $\mathrm{HCO}_{3}^{-}$ & & 3.19 & 2.67 & 3.33 & 2.91 \\
\hline $\mathrm{Cl}^{-1}$ & & 14.30 & 11.09 & 14.12 & 12.25 \\
\hline Available Water & $\mathrm{cm}^{3} \cdot \mathrm{cm}^{-3}$ & 0.1584 & 0.1906 & 0.1589 & 0.2089 \\
\hline Bulk Density & $\mathrm{mg} \cdot \mathrm{m}^{-3}$ & 1.38 & 1.46 & 1.37 & 1.48 \\
\hline Particle Density & & 2.58 & 2.59 & 2.56 & 2.45 \\
\hline Total Porosity & $\%$ & 47 & 44 & 47 & 40 \\
\hline
\end{tabular}

Design (RCBD) in systematic arrangement with three replications determine the type of design and divided into plots according to experimental design. The experimental plots were separated by earth banks ( $1.5 \mathrm{~m}$ wide and $0.5 \mathrm{~m}$ high). To prevent seepage of water and nutrients between experimental plots. The sub-plot area was $4 \mathrm{~m} \times 5 \mathrm{~m}$. The treatments were:

1) Furrow irrigation $\left(I_{0}\right)$ as a control application.

2) Surface drip irrigation $\left(I_{1}\right)$.

3) Sub-surface drip emitters at $10 \mathrm{~cm}$ depth $\left(\mathrm{I}_{2}\right)$.

4) Sub-surface drip emitters at $20 \mathrm{~cm}$ depth $\left(\mathrm{I}_{3}\right)$. 
5) Sub-surface drip emitters at $30 \mathrm{~cm}$ depth $\left(\mathrm{I}_{4}\right)$.

The experimental design and treatments were illustrated in Figure 4.

\section{Evaluation of Drip Irrigation System}

Calibration of drip system emitter discharge was done every 20 minute period by placing four cylinders $(1000 \mathrm{ml})$ in any experimental unit distributed in four locations, one for any quarter. The evaluation of the system was done under three pressures 100, 150 and $200 \mathrm{kPa}$. The following calibration parameters were measured:

a) Emitters Coefficient uniformity.

b) Emitters Distribution uniformity.

c) Proportion of Variance conjugations emitters.

d) Application Efficiency.

Uniformity coefficient was calculated using the following equation [10]:

$$
C u=(1-\Sigma x / M n) \times 100
$$

$C u=$ Coefficient uniformity (\%).

$\Sigma_{X}=$ Total deviations from the discharge rate $\left(\mathrm{h} \mathrm{cm}^{-3}\right)$.

$M=$ Average discharge raster's $\left(\mathrm{h} \mathrm{cm}^{-3}\right)$.

$n=$ Number of raster.

The second parameter was distribution uniformity using the following equation [11]:

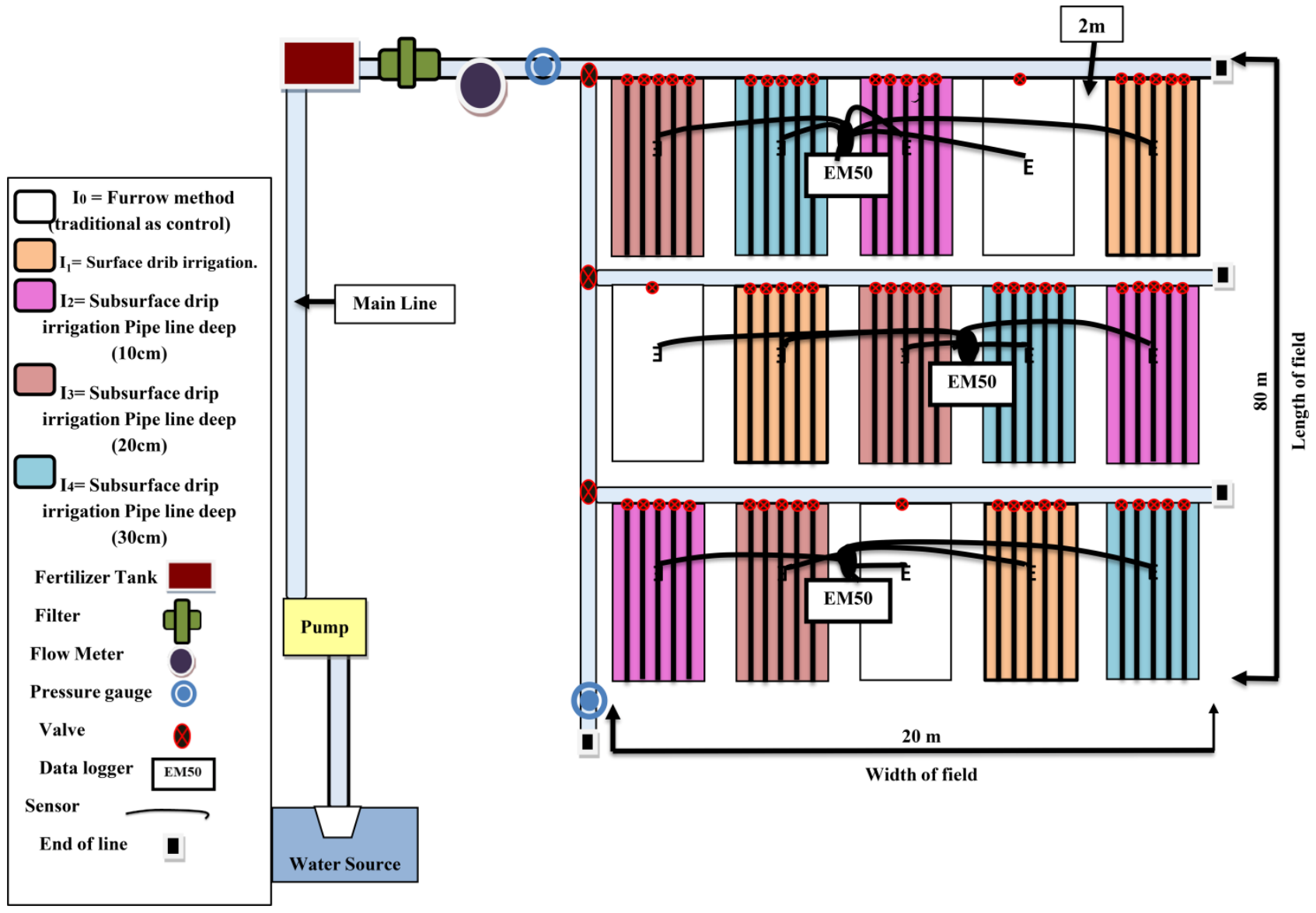

Figure 4. Experimental Layout. 


$$
D u(1 / 4)=(D i q / D a c) \times 100
$$

where:

$D u(1 / 4)=$ Uniformity Distribution for the lowest quarter (\%).

Diq $=$ Average water depths for the lowest quarter.

$D a c=$ Average total water depths.

The proportion of variance conjugations emitters also measured using following equation [12]:

$$
q_{\mathrm{Net}}=\frac{q_{\max }-q_{\min }}{q_{\max }} \times 100
$$

$q_{\text {Net }}=$ proportion of variance conjugations emitters (\%).

$q_{\max }=$ highest discharge $(\mathrm{h} / \mathrm{L})$.

$q_{\text {min }}=$ less discharge $(\mathrm{h} / \mathrm{L})$.

The application efficiency for drip irrigation methods measured using following equation [13]:

$$
E a=\frac{e q_{\min } T}{V} \times 100
$$

where:

$$
\begin{aligned}
& E a=\text { application efficiency }(\%) . \\
& e=\text { the total numbers of emitters. } \\
& q_{\min }=\text { minimum emitter flow rate. } \\
& T=\text { total irrigation time. } \\
& V=\text { total amount of water applied. }
\end{aligned}
$$

The application efficiency for furrow irrigation method measured using following equation [14]:

$$
E a=N D I / G D I
$$

where:

$$
\begin{aligned}
& N D I=\text { Net depth of irrigation }(\mathrm{mm}) . \\
& G D I=\text { Gross depth of irrigation }(\mathrm{mm}) .
\end{aligned}
$$

\section{Sensor System}

The Sensor System Decagon devices were installed in the field are consisted of two data loggers type Em 50, the data was recorded by the computer, each of data loggers connected to five sensors type 5TE and GS3. The sensors were installed at three depths, $(10,20$ and $30 \mathrm{~cm})$ for two replicates. Data loggers record volumetric moisture content, temperature and EC of soil every one hour and then the data is saved onto a computer. Data Trac3 program was used to identify and sensors data graph, as it connects the computer with the Em50 Data Logger. Then the program transfers and converts the data format stored in the Em50 Data Logger's memory to another format that Data Trac3 deals with. The ports of sensors were distributed according to irrigation treatments as follows:
1) Furrow irrigation $\left(I_{0}\right)=P 1$.
2) Surface drip irrigation $\left(I_{1}\right)=P 2$.
3) Sub-surface drip emitters at $10 \mathrm{~cm}$ depth $\left(\mathrm{I}_{2}\right)=\mathrm{P} 3$. 
4) Sub-surface drip emitters at $20 \mathrm{~cm}$ depth $\left(\mathrm{I}_{3}\right)=\mathrm{P} 4$.

5) Sub-surface drip emitters at $30 \mathrm{~cm}$ depth $\left(\mathrm{I}_{4}\right)=\mathrm{P} 5$.

\section{Irrigation Treatments and Management}

Irrigation treatments consisted mainly of furrow irrigation. The plots of this treatment were initially irrigated by surface irrigation because they were planted in rows in flat plots. Thirty days after sowing, the furrows were done between plant rows using a furrowing machine. The irrigation was applied by tube system with valves and flow meter to measure the amount of water applied to each experimental unit of this treatment. The surface and subsurface drip irrigation were done using drip irrigation system (Ro-drip). Irrigation scheduling was done according to the depletion of soil moisture content at three soil depths $(0-10,10$ 20 and $20-30 \mathrm{~cm}$ ) depending on the sensor system. Thus, when $50 \%$ of the available water was depleted, irrigation was done. Soil moisture content was calculated according to the following equation [15]:

$$
d=\left(\theta_{f c}-\theta_{w}\right) \times D
$$

where:

$d=$ depth of water applied $(\mathrm{mm})$.

$\theta_{f c}=$ Volumetric water content at field capacity $\left(\mathrm{cm}^{3} \cdot \mathrm{cm}^{-3}\right)$.

$\theta_{w}=$ Volumetric water content before irrigation $\left(\mathrm{cm}^{3} \cdot \mathrm{cm}^{-3}\right)$.

$D=$ Soil depth to be wetted at irrigation.

The water amount which was applied to experimental treatments by drip irrigation system calculated according to the following equation [14]:

$$
N D I=R Z D \times W H C \times P d \times P w
$$

where:

$N D I=$ Net Irrigation Depth.

$R Z D=$ Rhizosphere Depth.

$W H C=$ Water bearing Capacity $\left(\mathrm{mm}\right.$ of water $\left.\cdot \mathrm{cm}^{-1}\right)$.

$P d=$ Percent of depletion.

$P W=$ Percent of wetting.

Water consumptive use (evaporation) of the crop was measured by using the following water balance equation [16]:

$$
(I+P+C)-\left(E T_{a}+D+R\right)=\mp \Delta s
$$

$I=$ irrigation $(\mathrm{mm})$.

$P=$ precipitation $(\mathrm{mm})$.

$C=$ capillaries $(\mathrm{mm})$.

$E T_{a}=$ actual evapotranspiration $(\mathrm{mm})$.

$D=$ deep percolation $(\mathrm{mm})$.

$R=$ rune off $(\mathrm{mm})$.

$\Delta s=$ changes in the water storage during soil profile.

Water use efficiencies were determined [17]:

$$
W U E=G Y / W A
$$

where: 
$W U E=$ water use efficiency $\left(\mathrm{kg} \cdot \mathrm{m}^{-3}\right)$.

$G Y=$ total grain yield $\left(\mathrm{kg} \cdot \mathrm{ha}^{-1}\right)$.

$W A=$ water applied $\left(\mathrm{m}^{3} \cdot \mathrm{ha}^{-1}\right)$.

\section{Results and Discussion}

\section{Evaluation of irrigation methods}

Figure 5 shows the effect of pressures (100, 150 and 200) $\mathrm{kPa}$ on coefficient uniformity and application efficiency of water for furrow irrigation method for the seasons 2016 and 2017, where the highest value of coefficient uniformity were $78 \%$ and $76 \%$ and application efficiency were $67 \%$ and $65 \%$ at pressures 100 and $150 \mathrm{kPa}$ for the 2016 and 2017 seasons; respectively. The reason there was an inverse relationship between operating pressure, coefficient uniformity and application efficiency as the pressure increases, the coefficient uniformity decreases, and application efficiency [18] [19].

As well as for the subsurface drip irrigation Figure 6 the highest values were

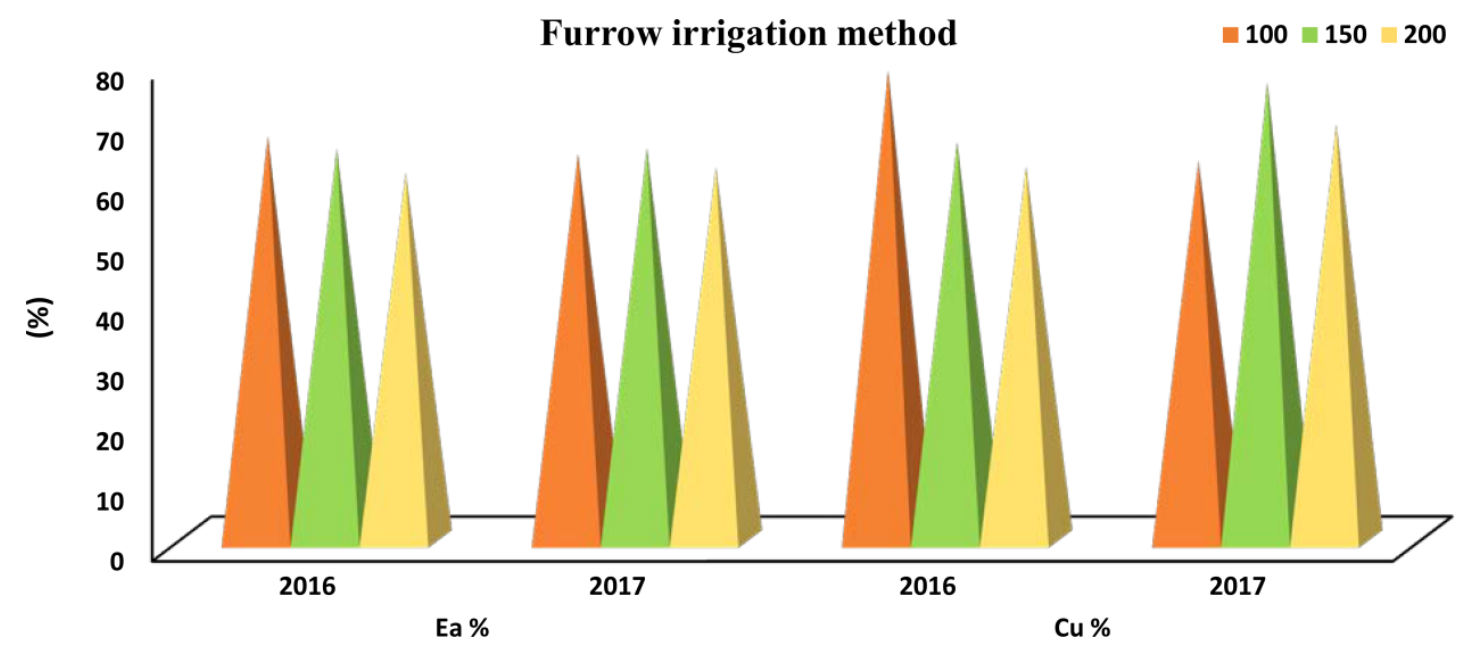

Figure 5. Evaluation furrow irrigation method.

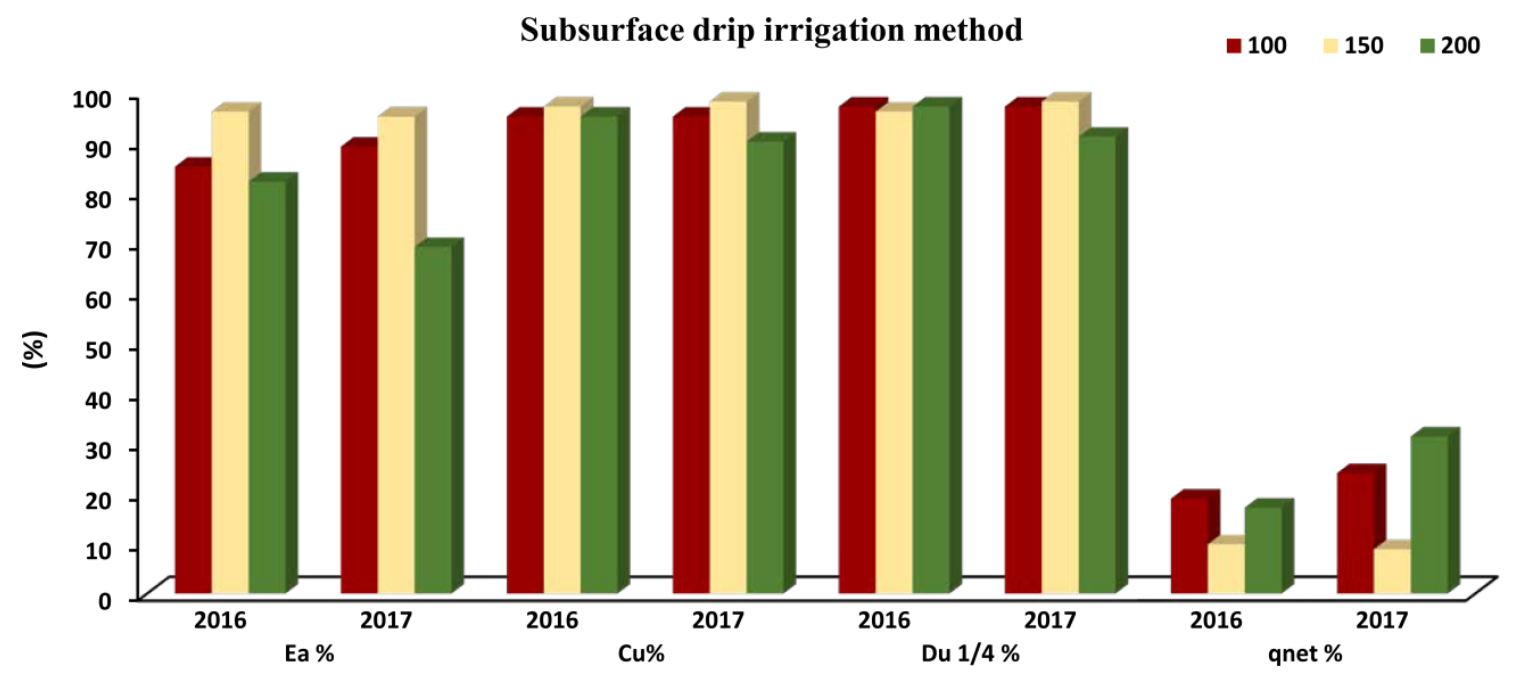

Figure 6. Evaluation subsurface drip irrigation method. 
97\%, 99\% and 96\% for application efficiency, uniformity distribution and coefficient uniformity; respectively and the lowest proportion of variance was $9.8 \%$ for pressure $100 \mathrm{kPa}$ and for 2016 season. While for the 2017 season the highest values were $98 \%, 98 \%$ and $95 \%$ for application efficiency, uniformity distribution and coefficient uniformity; respectively and lowest proportion of variance was $8.8 \%$ for pressure $150 \mathrm{kPa}$. The low pressure causes a uniform flow of water distribution and good homogeneity of distribution between the droplets and water consistency along the drip line thus, the application efficiency of water for subsurface drip irrigation system was high [20] [21].

As for surface drip irrigation, the highest values were $98 \%, 97 \%$ and $89 \%$ and $97 \%, 96 \%$ and $88 \%$ for application efficiency, uniformity distribution and coefficient uniformity; respectively, and the lowest proportion of variance were (7.3 and 10.1) \% for pressure of $200 \mathrm{kPa}$ for the 2016 and 2017 seasons; respectively Figure 7. Whereas, the increase in pressure gave the best coefficient uniformity of distribution of drippers, uniformity distribution and less proportion of variance, and thus the best application efficiency of water. Subsurface drip requires less pressure and therefore less energy consumption and less cost of operation [22] and [23].

\section{Volumetric moisture content of different irrigation methods}

Figure 8 and Figure 9 show the volumetric moisture content of all irrigation treatments according to the data sensors at three depths of 10,20 and $30 \mathrm{~cm} \mathrm{ac}$ cording to the growth plant stages. The middle stage at $20 \mathrm{~cm}$ depth need more net irrigation and as a result high moisture content for all treatments, due to increased plant height, canopy cover, flowers, ear initial and increased water consumption.

The lack of moisture at this stage reduced the grain size and reduced the yield,

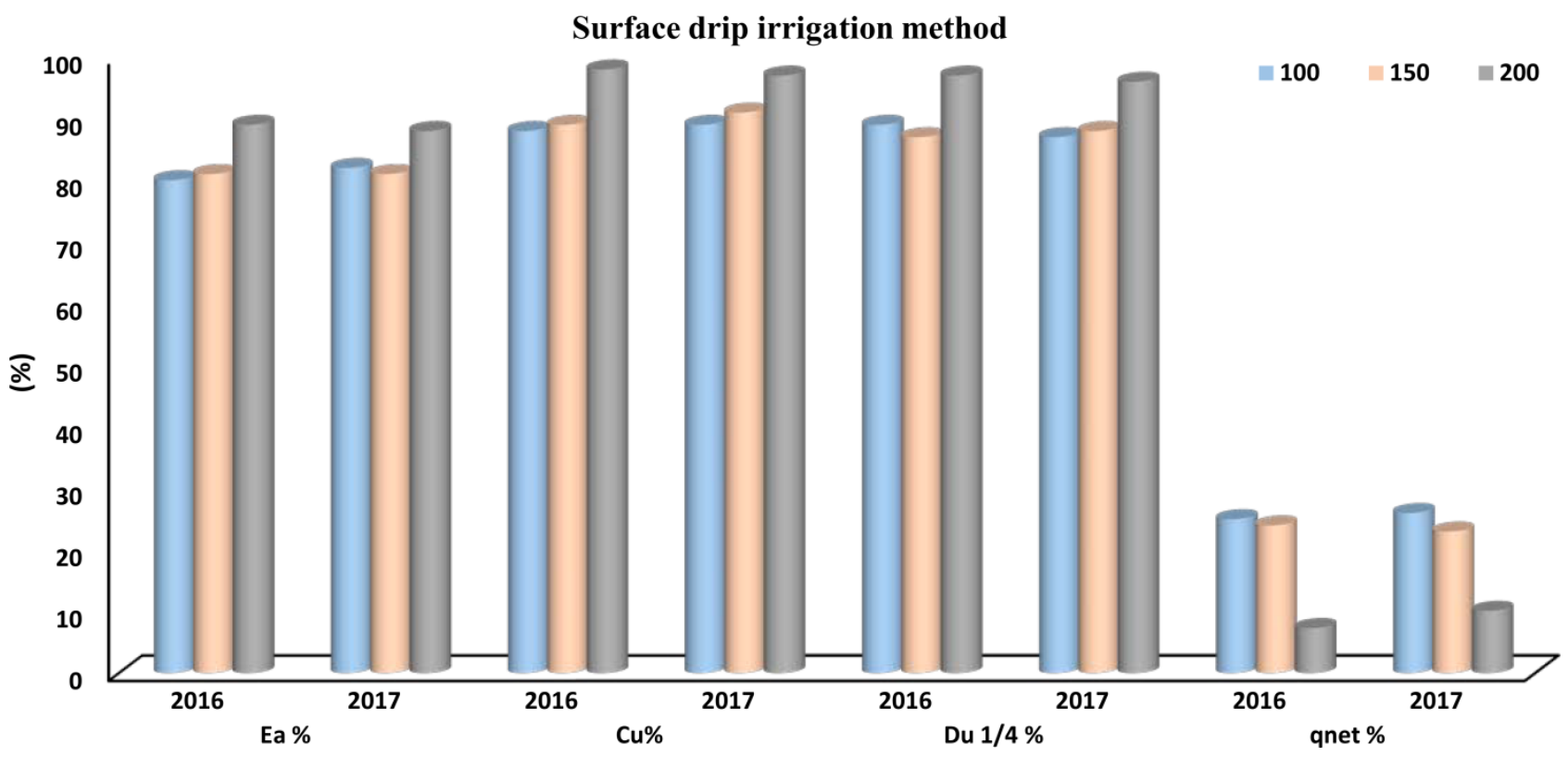

Figure 7. Evaluation subsurface drip irrigation method. 


\section{thamer S1}

\section{Location:}

Start: 07/08/2016 06:00 PM

Stop: 27/08/2016 03:00 PM

— P1 - 5TE: $\mathrm{m}^{3} / \mathrm{m}^{3}$ VWC $(10 \mathrm{~cm})$

— P2 - 5TE: $\mathrm{m}^{3} / \mathrm{m}^{3}$ VWC $(10 \mathrm{~cm})$

— P3 - 5TE: $\mathrm{m}^{3} / \mathrm{m}^{3}$ VWC $(10 \mathrm{~cm})$

P4 - 5TE: $\mathrm{m}^{3} / \mathrm{m}^{3} \mathrm{VWC}(10 \mathrm{~cm})$

— P5 - 5TE: $\mathrm{m}^{3} / \mathrm{m}^{3}$ VWC $(10 \mathrm{~cm})$

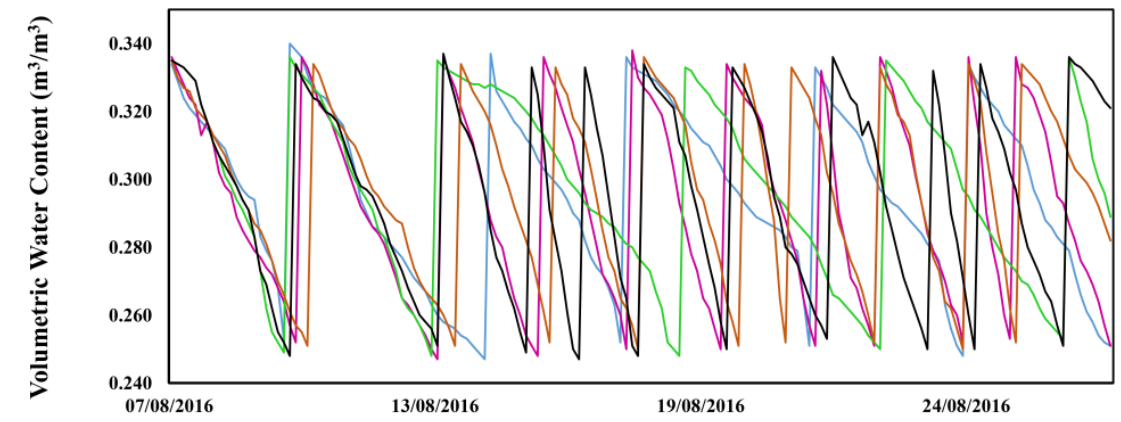

\begin{tabular}{|c|c|c|c|c|c|}
\hline & $\begin{array}{c}\mathrm{P} 1-\mathrm{m}^{3} / \mathrm{m}^{3} \mathrm{VWC} \\
5 T E(10 \mathrm{~cm}) \\
\end{array}$ & $\begin{array}{c}P 2-\mathrm{m}^{3} / \mathrm{m}^{3} \mathrm{VWC} \\
5 T E(10 \mathrm{~cm})\end{array}$ & $\begin{array}{c}\mathrm{P} 3-\mathrm{m}^{3} / \mathrm{m}^{3} \mathrm{VWC} \\
5 T E(10 \mathrm{~cm})\end{array}$ & $\begin{array}{c}P 4-\mathrm{m}^{3} / \mathrm{m}^{3} \mathrm{VWC} \\
\text { 5TE }(10 \mathrm{~cm})\end{array}$ & $\begin{array}{c}\mathrm{P} 5-\mathrm{m}^{3} / \mathrm{m}^{3} \mathrm{VWC} \\
5 T E(10 \mathrm{~cm})\end{array}$ \\
\hline Avg : & 0.296 & 0.293131 & 0.2973 & 0.297 & 0.295663 \\
\hline Min : & 0.247 & 0.241 & 0.248 & 0.250 & 0.247 \\
\hline Max : & 0.343 & 0.338 & 0.336 & 0.336 & 0.337 \\
\hline Total : & $\mathrm{n} / \mathrm{a}$ & $\mathrm{n} / \mathrm{a}$ & $\mathrm{n} / \mathrm{a}$ & $\mathrm{n} / \mathrm{a}$ & $\mathrm{n} / \mathrm{a}$ \\
\hline Events : & $\mathrm{n} / \mathrm{a}$ & $\mathrm{n} / \mathrm{a}$ & $\mathrm{n} / \mathrm{a}$ & $\mathrm{n} / \mathrm{a}$ & $\mathrm{n} / \mathrm{a}$ \\
\hline
\end{tabular}

thamer S1

Created 28/11/2016 03:14:59 PM by $\mathrm{ECH}_{2} 0$ Data Trac version 3.13

\section{Location:}

Start: 27/08/2016 06:00 PM

Stop: 09/10/2016 09:00 PM

P1 - 5TE: $\mathrm{m}^{3} / \mathrm{m}^{3}$ VWC $(20 \mathrm{~cm})$

- P2 - 5TE: $\mathrm{m}^{3} / \mathrm{m}^{3} \mathrm{VWC}(20 \mathrm{~cm})$

P3 - 5TE: $\mathrm{m}^{3} / \mathrm{m}^{3} \mathrm{VWC}(20 \mathrm{~cm})$

- P4-5TE: $\mathrm{m}^{3} / \mathrm{m}^{3} \mathrm{VWC}(20 \mathrm{~cm})$

- P5 - 5TE: $\mathrm{m}^{3} / \mathrm{m}^{3} \mathrm{VWC}(20 \mathrm{~cm})$

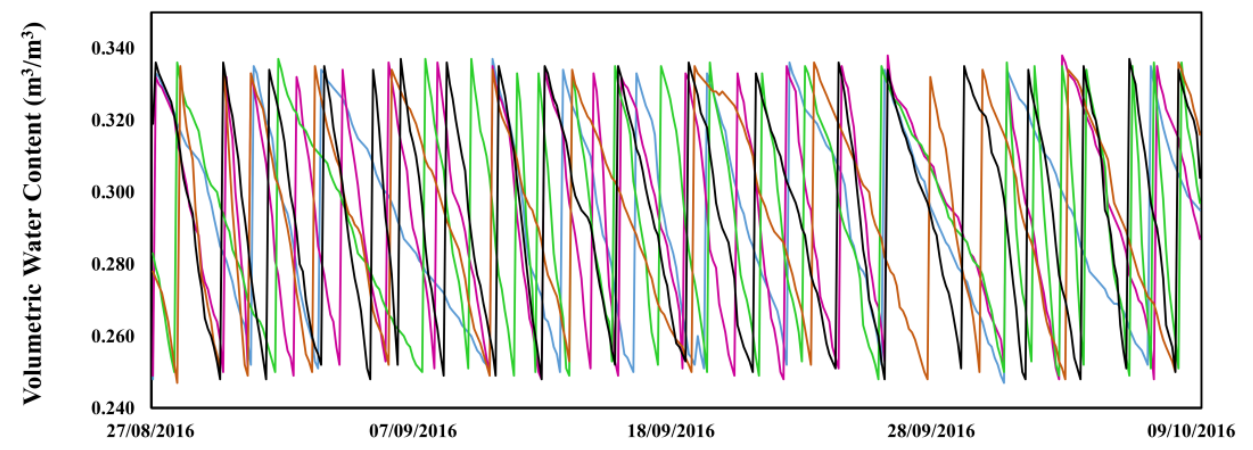

\begin{tabular}{|c|c|c|c|c|c|}
\hline & $\begin{array}{c}P 1-\mathrm{m}^{3} / \mathrm{m}^{3} \mathrm{VWC} \\
5 T E(20 \mathrm{~cm})\end{array}$ & $\begin{array}{c}P 2-\mathrm{m}^{3} / \mathrm{m}^{3} \mathrm{VWC} \\
5 T E(20 \mathrm{~cm})\end{array}$ & $\begin{array}{c}P 3-\mathrm{m}^{3} / \mathrm{m}^{3} \mathrm{VWC} \\
5 T E(20 \mathrm{~cm})\end{array}$ & $\begin{array}{c}P 4-\mathrm{m}^{3} / \mathrm{m}^{3} V W C \\
5 T E(20 \mathrm{~cm})\end{array}$ & $\begin{array}{c}P 5-\mathrm{m}^{3} / \mathrm{m}^{3} \mathrm{VWC} \\
5 T E(20 \mathrm{~cm})\end{array}$ \\
\hline Avg : & 0.294 & 0.294895 & 0.293 & 0.294 & 0.302 \\
\hline Min : & 0.247 & 0.238 & 0.248 & 0.247 & 0.248 \\
\hline Max : & 0.345 & 0.338 & 0.337 & 0.336 & 0.336 \\
\hline Total : & $\mathrm{n} / \mathrm{a}$ & $\mathrm{n} / \mathrm{a}$ & $\mathrm{n} / \mathrm{a}$ & $\mathrm{n} / \mathrm{a}$ & $\mathrm{n} / \mathrm{a}$ \\
\hline Events : & $\mathrm{n} / \mathrm{a}$ & $\mathrm{n} / \mathrm{a}$ & $\mathrm{n} / \mathrm{a}$ & $\mathrm{n} / \mathrm{a}$ & $\mathrm{n} / \mathrm{a}$ \\
\hline
\end{tabular}

Created 28/11/2016 03:14:59 PM by $\mathrm{ECH}_{2} 0$ Data Trac version 3.13 


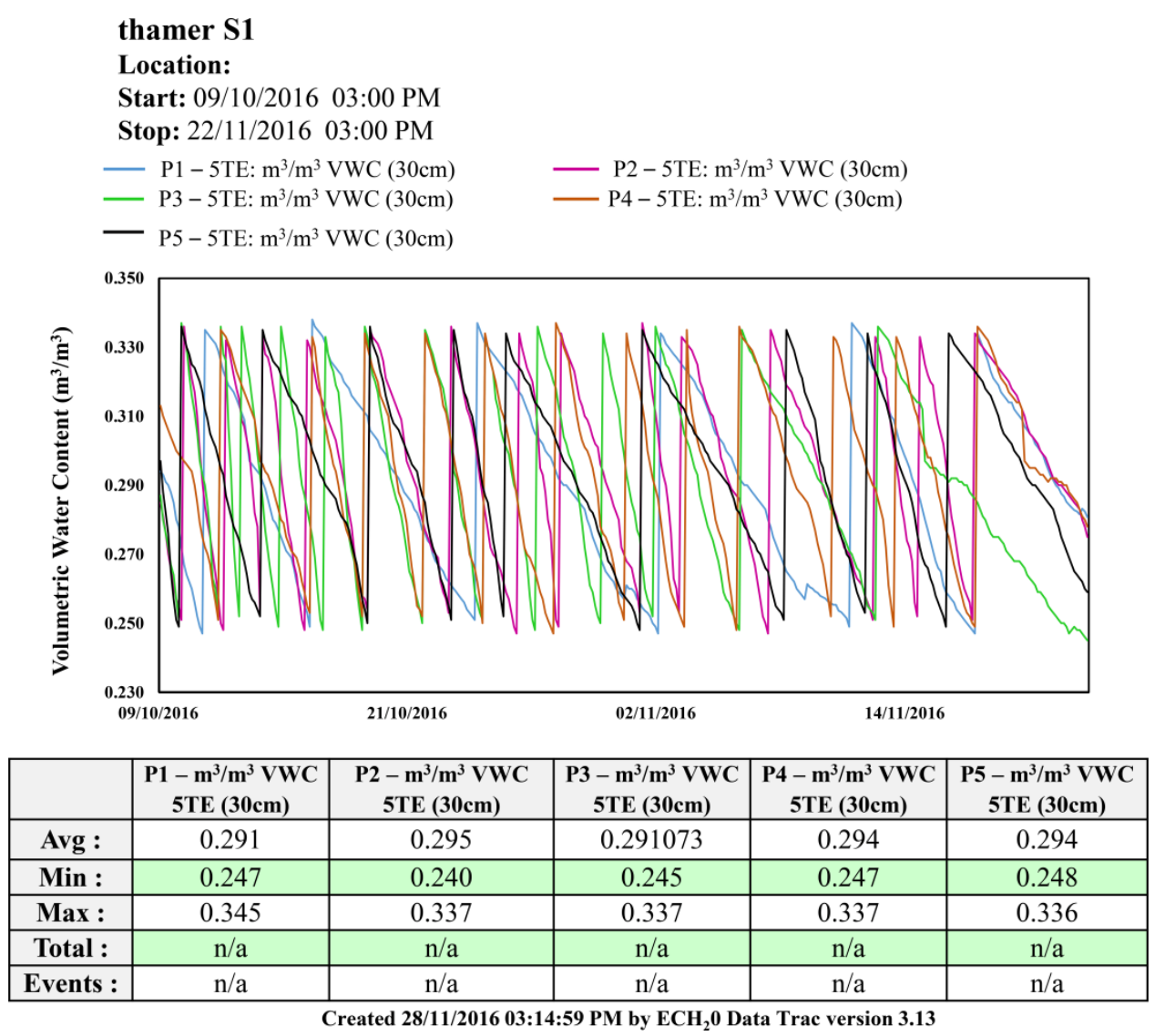

Figure 8. Volumetric moisture content of different irrigation methods at 2016 season.

so it is necessary to provide suitable moisture at this stage, these results was consistent with [24].

The lowest moisture content in surface drip irrigation $\mathrm{I}_{1}$ treatment $\mathrm{P} 2$ were $(0.242,0.238,0.240) \mathrm{cm}^{3} \cdot \mathrm{cm}^{-3}$ and $(0.238,0.240,0.240) \mathrm{cm}^{3} \cdot \mathrm{cm}^{-3}$ for 10,20 and $30 \mathrm{~cm}$ depths for 2016 and 2017 seasons respectively. Treatment P2 surface drip irrigation $\mathrm{I}_{1}$ requires more net irrigation because of the low moisture content in the soil due to the high evaporation of water from the soil and the lowest irrigation network was in subsurface drip irrigation $\mathrm{P}_{4} \mathrm{I}_{3}$ because the emitters are below the surface of the soil and thus reduce evaporation.

The decrease in the volumetric moisture content indicates that the soil needs to use applied of water to reach the field capacity of water adequacy of the plant's requirement, these results was agree with [25]. The highest volumetric moisture content values were recorded for furrow irrigation $\mathrm{I}_{0}$ treatment $\mathrm{P} 1$ were $(0.343$, $0.345,0.345) \mathrm{cm}^{3} \cdot \mathrm{cm}^{-3}$ and $(0.343,0.348,0.345) \mathrm{cm}^{3} \cdot \mathrm{cm}^{-3}$ for depths 10,20 and $30 \mathrm{~cm}$ for 2016 and 2017 seasons, respectively, because the water flows in the streams and it needs large quantities of water to reach the volumetric moisture content at the effective rhizosphere to the field capacity, these results was agree with [26].

\section{Consumptive use and Water applied}

Water Consumptive use ETa depends on the type of crop, the period of the 
thamer S2

Location:

Start: 07/08/2017 12:00 PM

Stop: 26/08/2017 9:00 PM

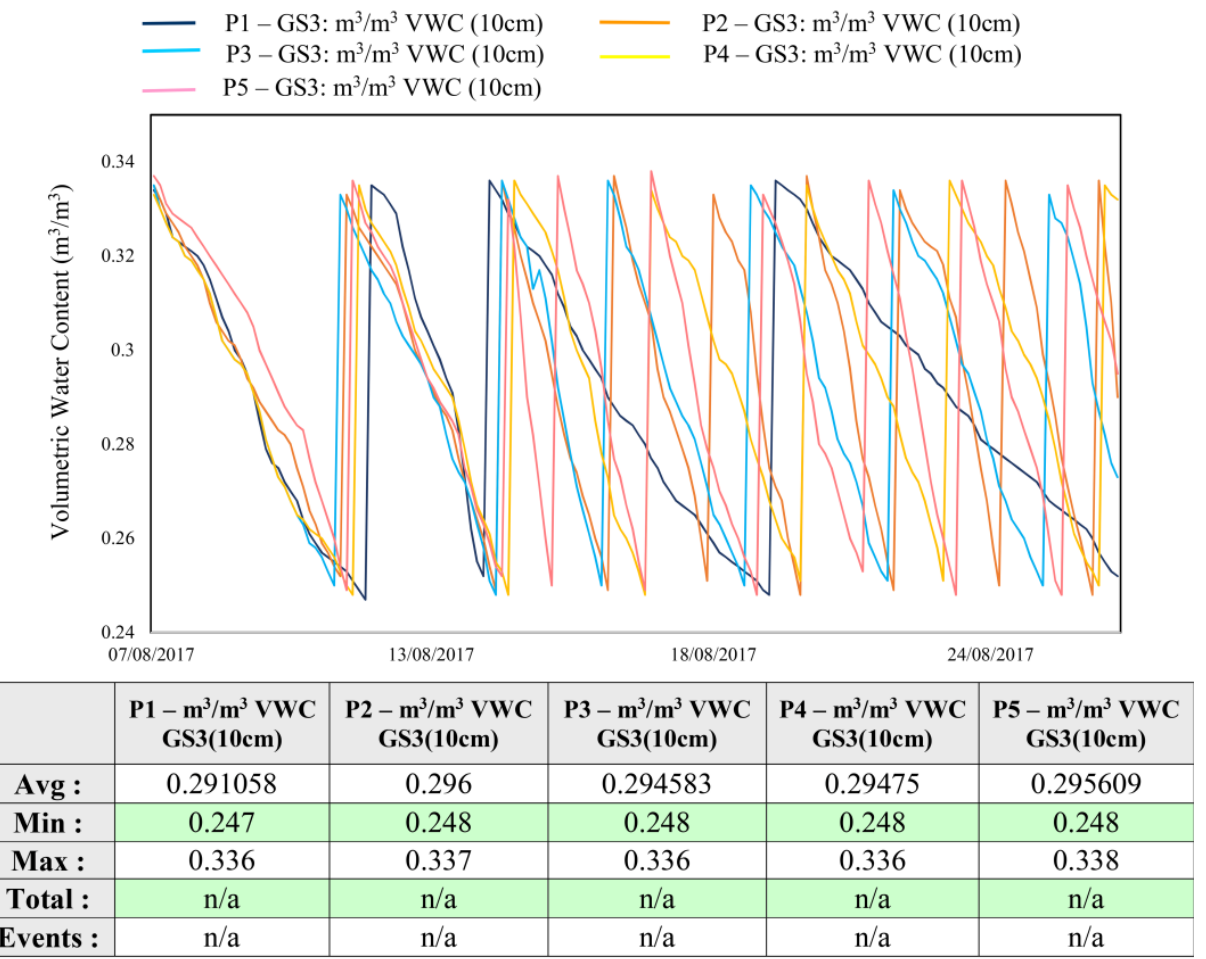

Created 11/24/2017 9:43:06 AM by $\mathrm{ECH}_{2} 0$ Data Trac version 3.13

thamer $\mathrm{S}$

Start: 27/08/2017 12:00 AM

Stop: 10/09/2017 9:00 PM

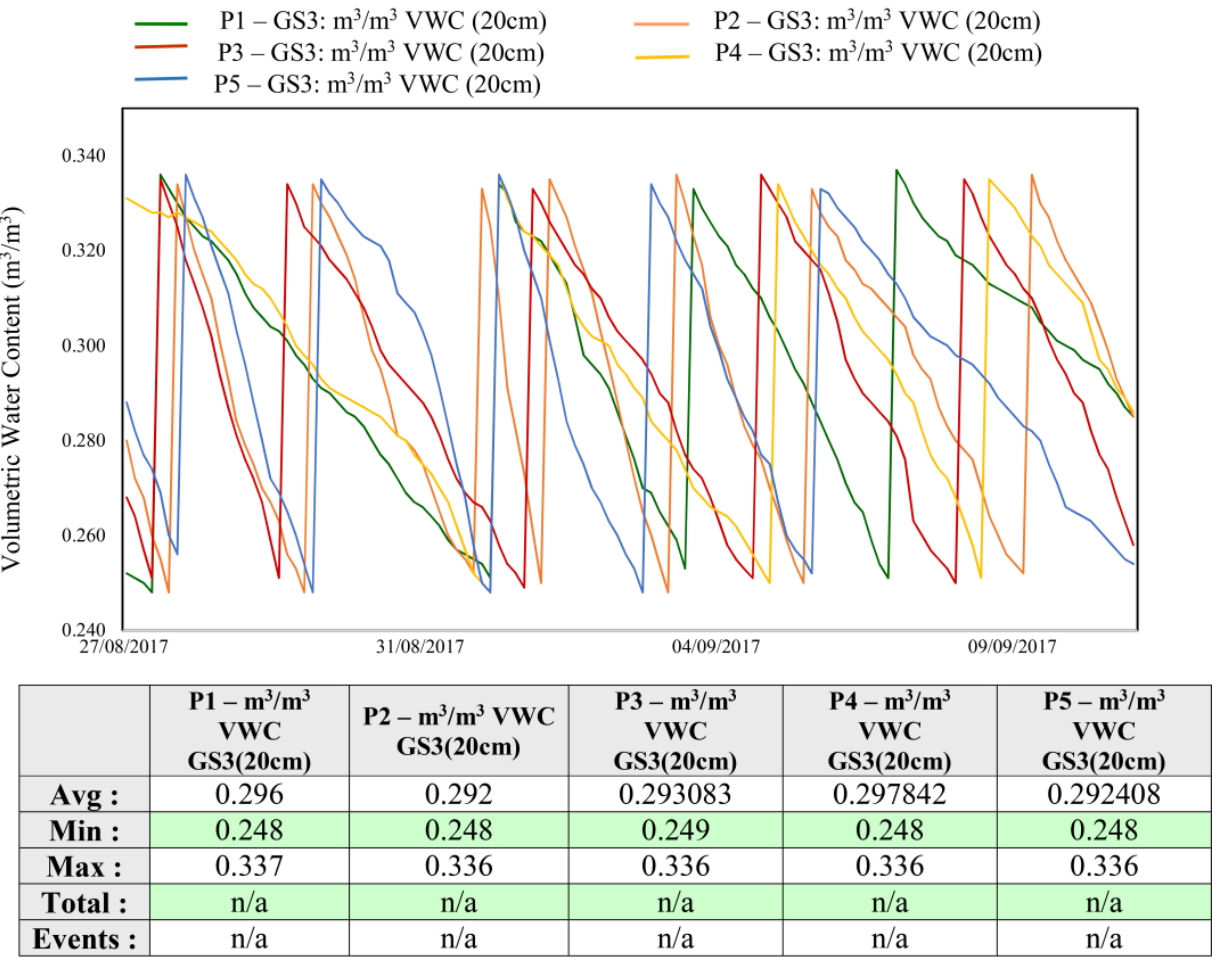

Created 11/24/2017 9:43:06 AM by $\mathrm{ECH}_{2} 0$ Data Trac version 3.13 


\section{thamer S2}

Location:

Start: 11/09/2017 12:00 AM

Stop: 19/11/2017 9:00 PM

P $1-$ GS3: $\mathrm{m}^{3} / \mathrm{m}^{3} \mathrm{VWC}(30 \mathrm{~cm})$

- P3-GS3: $\mathrm{m}^{3} / \mathrm{m}^{3} \mathrm{VWC}(30 \mathrm{~cm})$

P2 - GS3: $\mathrm{m}^{3} / \mathrm{m}^{3} \operatorname{VWC}(30 \mathrm{~cm})$
P4 - GS3: $\mathrm{m}^{3} / \mathrm{m}^{3} \operatorname{VWC}(30 \mathrm{~cm})$

- P5 - GS3: $\mathrm{m}^{3} / \mathrm{m}^{3} \mathrm{VWC}(30 \mathrm{~cm})$

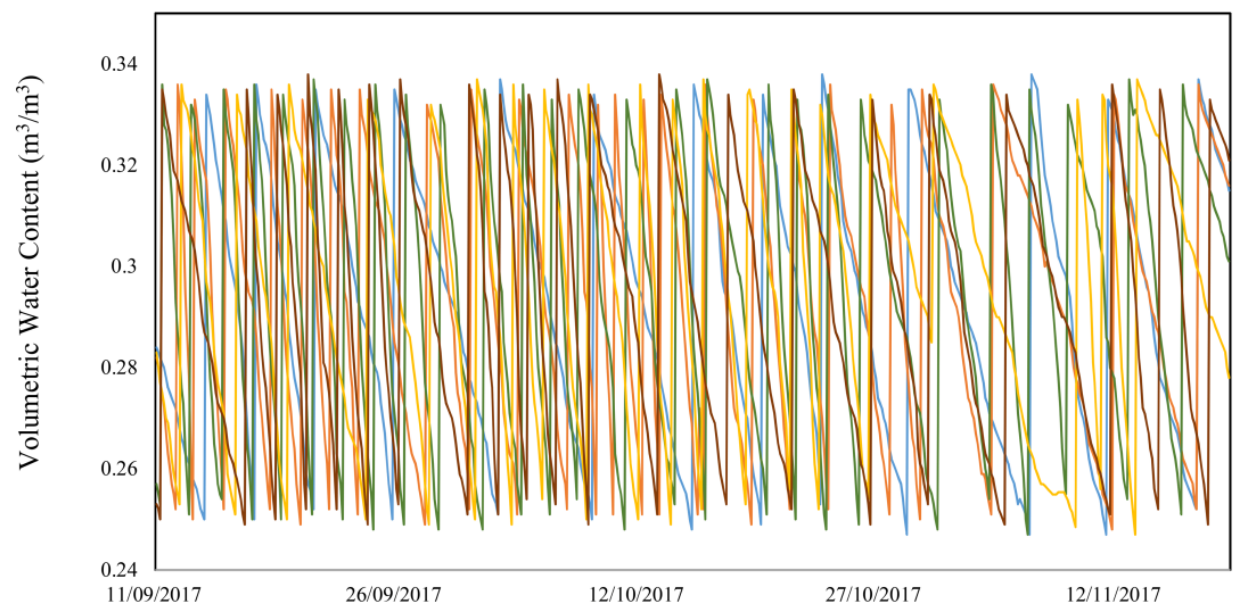

\begin{tabular}{|l|c|c|c|c|c|}
\hline & $\begin{array}{c}\mathbf{P 1}-\mathbf{m}^{\mathbf{3}} / \mathbf{m}^{\mathbf{3}} \mathbf{V W C} \\
\mathbf{G S 3}(\mathbf{3 0} \mathbf{c m})\end{array}$ & $\begin{array}{c}\mathbf{P 2}-\mathbf{m}^{\mathbf{3}} / \mathbf{m}^{\mathbf{3}} \mathbf{V W C} \\
\mathbf{G S 3}(\mathbf{3 0} \mathbf{c m})\end{array}$ & $\begin{array}{c}\mathbf{P 3}-\mathbf{m}^{\mathbf{3}} / \mathbf{m}^{\mathbf{3}} \mathbf{V W C} \\
\mathbf{G S 3}(\mathbf{3 0} \mathbf{c m})\end{array}$ & $\begin{array}{c}\mathbf{P 4}-\mathbf{m}^{\mathbf{3}} / \mathbf{m}^{\mathbf{3}} \mathbf{V W C} \\
\mathbf{G S 3}(\mathbf{3 0} \mathbf{c m})\end{array}$ & $\begin{array}{c}\mathbf{P 5}-\mathbf{m}^{\mathbf{3}} / \mathbf{m}^{\mathbf{3}} \mathbf{V W C} \\
\mathbf{G S 3}(\mathbf{3 0} \mathbf{c m})\end{array}$ \\
\hline Avg : & 0.292976887 & 0.294 & 0.294789 & 0.296028 & 0.293484 \\
\hline Min : & 0.247 & 0.248 & 0.247 & 0.247 & 0.249 \\
\hline Max : & 0.338 & 0.336 & 0.337 & 0.337 & 0.338 \\
\hline Total : & $\mathrm{n} / \mathrm{a}$ & $\mathrm{n} / \mathrm{a}$ & $\mathrm{n} / \mathrm{a}$ & $\mathrm{n} / \mathrm{a}$ & $\mathrm{n} / \mathrm{a}$ \\
\hline Events : & $\mathrm{n} / \mathrm{a}$ & $\mathrm{n} / \mathrm{a}$ & $\mathrm{n} / \mathrm{a}$ & $\mathrm{n} / \mathrm{a}$ & $\mathrm{n} / \mathrm{a}$ \\
\hline
\end{tabular}

Created 11/24/2017 9:43:06 AM by $\mathrm{ECH}_{2} 0$ Data Trac version 3.13

Figure 9. Volumetric moisture content of different irrigation methods at 2017 season.

growing season, climatic factors, management practices, soil type and irrigation method. The consumptive use values for maize crop were varied according to the irrigation method applied, as the consumptive use values that resulted through the application of the water balance equation (i.e. Equation (8)). Figure 10 and Figure 11 show the highest value of consumptive use was for the furrow irrigation treatments $\left(\mathrm{I}_{0}\right)$ which ranged between 707.91 and $689.96 \mathrm{~mm} \cdot \mathrm{season}^{-1}$ for the 2016 and 2017 seasons; respectively.

While the lowest of consumptive use was for subsurface drip irrigation treatments, emitters depth of $20 \mathrm{~cm}\left(\mathrm{I}_{3}\right)$, were 313.93 and $293.50 \mathrm{~mm} \cdot$ season $^{-1}$, with a decrease ranging between 55 and 57\% compared with the treatment of furrow irrigation as shown in Figures (39 and 40) for the seasons 2016 and 2017; respectively. Thus, the reason for the decrease was due to the applied method of irrigation at the effective rhizosphere, as the wet area is determined by the soil around the emitters under the soil surface and the volume of moisture and the wetting in subsurface drip irrigation were inside the soil without wetting the soil surface. Therefore, evaporation decreased from the surface of the soil and extends irrigation periods, which was reflected in less water consumptive use of the plant. In addition to a little deep percolation with no surface runoff and the decrease in 


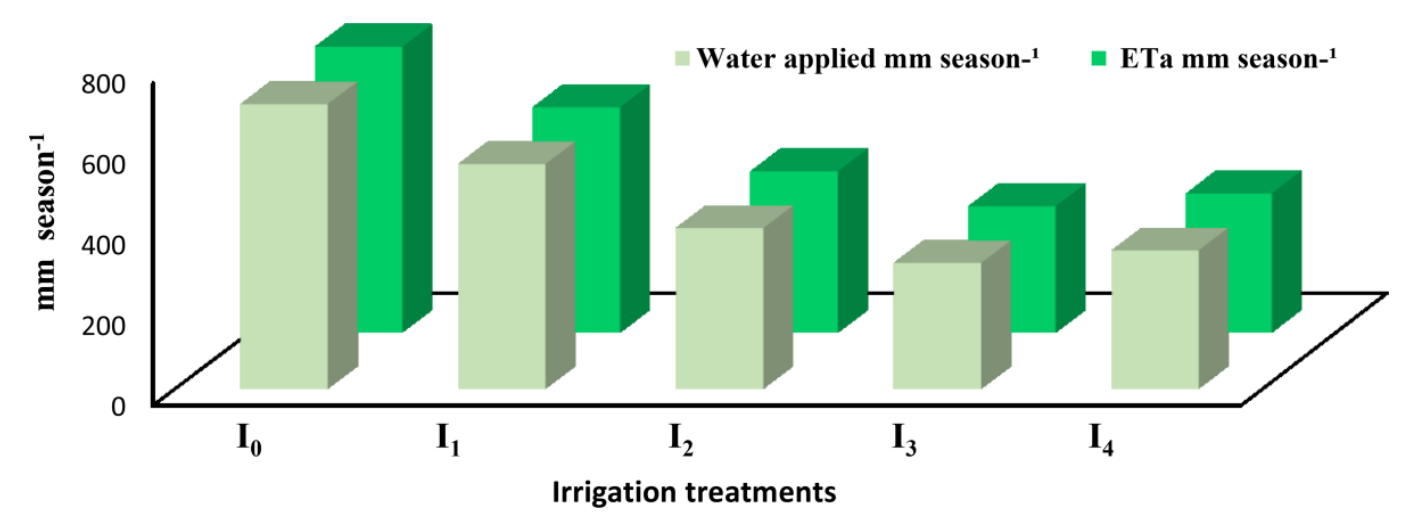

Figure 10. Consumptive use and Water applied at 2016 season.

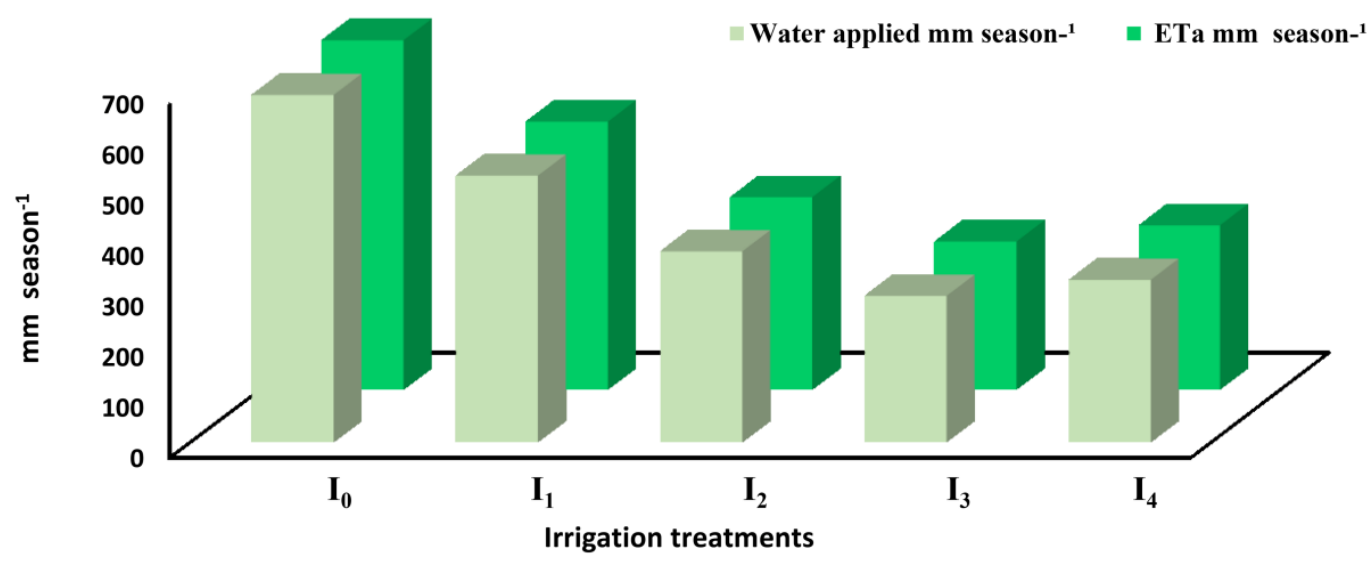

Figure 11. Consumptive use and Water applied at 2017 season.

the amount of water added as a result of keeping the soil moisture These results agreed by [27] and [28].

The highest amount of water applied was for furrow irrigation treatment $\mathrm{I}_{0}$, which amounted to 705.77 and $687.03 \mathrm{~mm} \cdot$ season $^{-1}$ for 2016 and 2017 seasons; respectively. Besides, the lowest amount of water applied was in the treatment of subsurface drip irrigation drippers at a depth of $20 \mathrm{~cm} \mathrm{I}_{3} 312.48$ and 291.20 $\mathrm{mm} \cdot$ season $^{-1}$, as shown in Figure 10 and Figure 11 for the 2016 and 2017 seasons; respectively. The reason behind the increase in the amount of water applied by furrow irrigation treatment $\mathrm{I}_{0}$ was due to the lack of control in the distribution of moisture over the rhizosphere, notably that the area of wet increases outside the rhizosphere. Moreover, the exposure of the moistened soil surface to the sunlight radiation increases accordingly as evaporation; and hence, water losses resulting from surface run-off and deep percolation, as well as due to the low efficiency of the addition, and then it was reported between $67 \%$ and $65 \%$ for furrow irrigation treatment and between $96 \%$ and $95 \%$ for the subsurface drip irrigation treatments and between $89 \%$ and $88 \%$ for surface drip irrigation for the 2016 and 2017 seasons; respectively. This has been shown in Figure 8 and Figure 9. This reveals the demand to add more water to reach the soil moisture to the field capacity and requirements of plant. Previous studies have indicated that subsurface drip irrigation reduces the amount of water applied 
between $30 \%$ and $60 \%$ compared with traditional methods.

Subsurface drip irrigation is characterized by direct contact with the rhizosphere and its distribution of water has two directions, vertically and horizontally by capillary action, which gives a more possibility for water to spread through the rhizosphere in addition to its advantage in that it is not directly exposed to sunlight radiation. This in turn reduces evaporation process and its impact. Also, soil particles and the different pores have an effect on consumptive use that enhanced by high temperatures in the growing months. This also led to an increase in water evaporation from the soil surface shown in Figure 2, as indicated by the results in the different values of consumptive use for the 2016 season; it was higher than that of 2017 season in all treatments. These results were agreed by [29] [30] and [31].

\section{Grain Yield and Water Use Efficiency WUE:}

The increase in Water Use Efficiency (WUE) for $\mathrm{I}_{3}$ treatment as shown in Figure 12) was due to the increase in the grain yield, which reached to 8.8 and $9.3 \mathrm{t} \cdot \mathrm{ha}^{-1}$ as shown in Figure 13), and a decrease in the amount of water that reached to 313.93 and $293.50 \mathrm{~mm} \cdot$ season $^{-1}$ as shown in Figure 10 and Figure 11

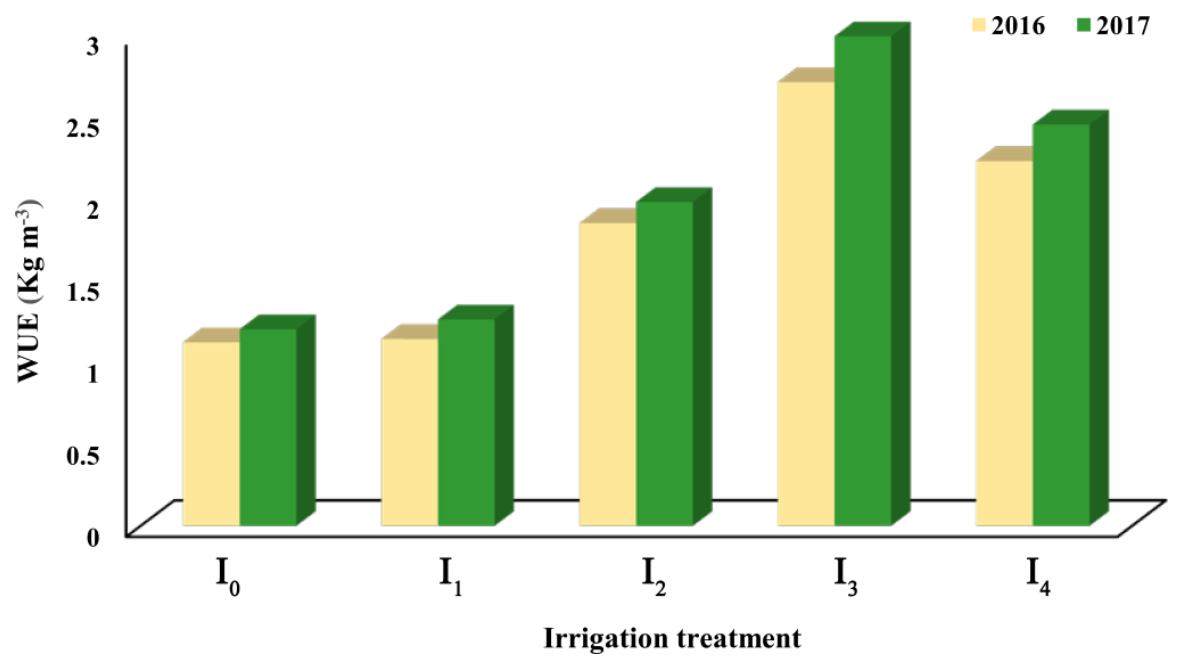

Figure 12. Water Use Efficiency for the 2016 and 2017 seasons.

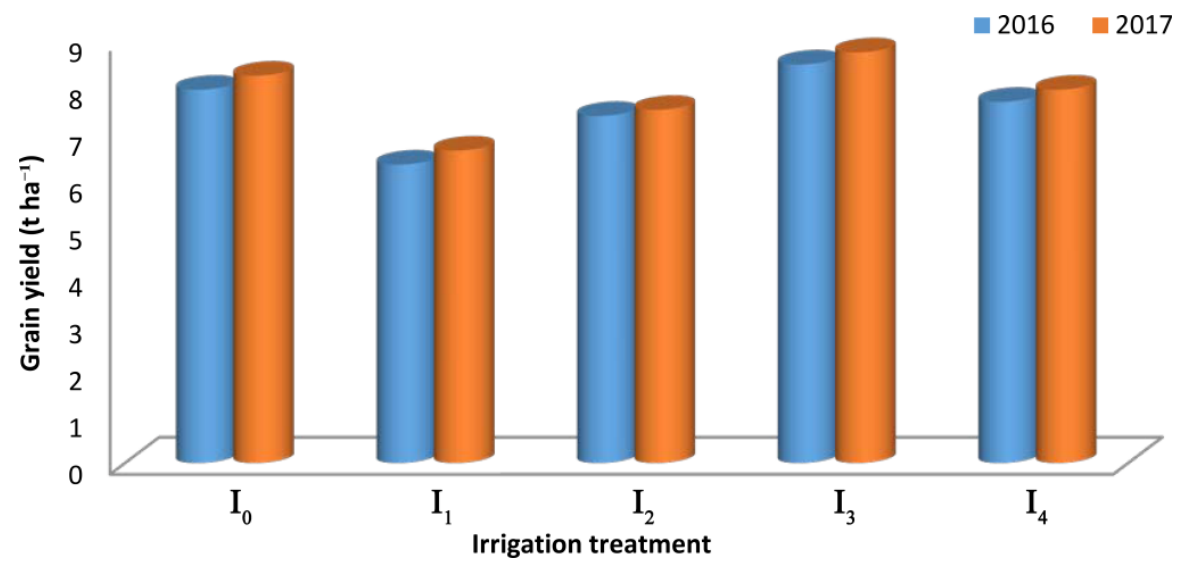

Figure 13. Maize Grain Yield for the 2016 and 2017 seasons. 
for the seasons 2016 and 2017; respectively and compared with $I_{0}$ treatment, which gave a grain yield similar to $\mathrm{I}_{3}$ standard (i.e. 8.4 and 8.7) $\mathrm{t}$ ha ${ }^{-1}$. However, the amount of water consumed was more than double the amount of water consumed in $\mathrm{I}_{3}$ treatment (i.e. 707.91 and 689.96) mm.season ${ }^{-1}$ for the 2016 and 2017 seasons; respectively. The reason behind was the decrease in the amount of irrigation water added to $\mathrm{I}_{3}$ treatment and the actual evaporation is transpiration, where the decrease in consumptive use from the height of the plant to grain yield to increase water use efficiency. Such results have been agreed by [32] and [33].

The lack of sufficient moisture content in roots' area and the exposure of the plant to water stress, is reflected in the processes of cell expansion and division, and in the processes of decrease length stem and leaf growth, and the area of carbon assimilation as well as leaf area and leaf area index decrease. There is also the ability of the plant to transfer the products of assimilation among parts of the plant, where it has been noticed a decrease grain yield with low amounts of irrigation water and different treatments, which resulted in decrease in water use efficiency. These results have been agreed with [34] and [35].

The decrease in WUE for the $I_{0}$ irrigation treatment, which amounted between 1.12 and $1.20 \mathrm{~kg} \cdot \mathrm{m}^{-3}$ for the two seasons 2016 and 2017; respectively, was attributed to the increase in consumptive use of this treatment compared to other treatments, as shown in Figure 10 and Figure 11 for the 2016 and 2017 seasons; respectively. This caused a decrease in the WUE, although the result was close to the treatment of subsurface drip irrigation $\mathrm{I}_{3}$, as it was shown in Figure 12 for the 2016 and 2017 seasons; respectively.

The increasing in WUE depends on what can be reduced from the amount of water given to the crop without affecting the amount of yield produced. These results were agreed by [36] [37] and [38].

\section{Conclusions}

1) It is necessary to evaluate the irrigation methods used in irrigating crops to know the efficiency of the coefficient uniformity (\%) of water, uniformity Distribution (\%), proportion of variance and the application efficiency (\%) of applied water for different irrigation methods, where it was found that the subsurface drip irrigation gave the highest application efficiency, uniformity distribution and coefficient uniformity were $97 \%, 99 \%$ and $96 \%$ and $98 \%, 98 \%$ and $95 \%$; respectively and the lowest proportion of variance were $8.8 \%$ and $9.8 \%$ for 2016 and 2017 seasons; respectively.

2) Observation of the volumetric moisture content of different irrigation methods through the sensing system, placing the sensors in the rhizosphere, and scheduling irrigation by knowing the time and quantity of irrigation according to the needs of the plant throughout the growing season.

3) Popularization of the subsurface drip irrigation system and adopting a depth of $20 \mathrm{~cm}$, which gave the least amount of applied water and water consumption 
and the highest productivity and efficiency in water use compared to furrow irrigation and surface drip irrigation, which are affected by climatic conditions from high temperatures and low humidity during the maize growing season in central regions of Iraq.

\section{Acknowledgements}

Thanks to Ecole Doctorale en Sciences et Technologie, Lebanese University.

\section{Conflicts of Interest}

The authors declare no conflicts of interest regarding the publication of this paper.

\section{References}

[1] Piri, H. and Naserin, A. (2020) Effect of Different Levels of Water, Applied Nitrogen and Irrigation Methods on Yield, Yield Components and IWUE of Onion. Scientia Horticulturae, 268, Article ID: 109361.

https://doi.org/10.1016/j.scienta.2020.109361

[2] Umair, M., Hussain, T., Jiang, H., Ahmad, A., Yao, J., Qi, Y., et al. (2019) Water-Saving Potential of Subsurface Drip Irrigation for Winter Wheat. Sustainability, 11, Article No. 2978. https://doi.org/10.3390/su11102978

[3] Mansour, H.A., Hu, J., Pibars, S., Bao, H.F. and Liang, C. (2019) Effect of Pipes Installation by Modified Machine for Subsurface Drip Irrigation System on Maize Crop Yield Costs. Agricultural Engineering International: CIGR Journal, 21, 98-107.

[4] Howell, T.A. (2003) Irrigation Efficiency. In: Howell, T.A., Ed., Encyclopedia of Water Science, Marcel Dekker Inc., New York, 467-472.

[5] Behmanesh, J. (2020) Investigation of Water Volume Controller Emitter Effect on Water Distribution Uniformity in Micro-Irrigation Systems. Water and Soil Science, 30, 97-108.

[6] Van der Kooij, S., Zwarteveen, M., Boesveld, H. and Kuper, M. (2013) The Efficiency of Drip Irrigation Unpacked. Agricultural Water Management, 123, 103-110. https://doi.org/10.1016/j.agwat.2013.03.014

[7] Lamm, F.R., Colaizzi, P.D., Sorensen, R.B., Bordovsky, J.P., Dougherty, M., Balkcom, K., et al. (2021) A 2020 Vision of Subsurface Drip Irrigation in the USA. Transactions of the ASABE, 64, 1319-1343. https://doi.org/10.13031/trans.14555

[8] Hamami, L. and Nassereddine, B. (2020) Application of Wireless Sensor Networks in the Field of Irrigation: A Review. Computers and Electronics in Agriculture, 179, Article ID: 105782. https://doi.org/10.1016/j.compag.2020.105782

[9] Van Genuchten, M.T. (1980) A Closed-Form Equation for Predicting the Hydraulic Conductivity of Unsaturated Soils. Soil Science Society of America Journal, 44, 892-898. https://doi.org/10.2136/sssaj1980.03615995004400050002x

[10] Christiansen, J.E. (1942) Irrigation by Sprinkling. Vol. 4, University of California, Berkeley.

[11] Burt, C.M., Clemmens, A.J., Strelkoff, T.S., Solomon, K.H., Bliesner, R.D., Hardy, L.A., et al. (1997) Irrigation Performance Measures: Efficiency and Uniformity. Journal of Irrigation and Drainage Engineering, 123, 423-442. https://doi.org/10.1061/(ASCE)0733-9437(1997)123:6(423) 
[12] Wu, I.P. and Gitlin, H.M. (1974) Drip Irrigation Design Based on Uniformity. American Society of Agricultural Engineers, 17, 3.

[13] Nakayama, F.S. and Bucks, D.A. (Eds.). (2012) Trickle Irrigation for Crop Production: Design, Operation and Management. Elsevier, Amsterdam.

[14] Hajem, A.Y. and Yassin, H.I. (1992) Field Irrigation Systems Engineering. Iraqi Books House for Printing and Publishing, University of Mosul, Mosul.

[15] Richards, L.A. and Wadleigh, C.H. (1952) Soil Water and Plant Growth. Soil Science, 74, 264. https://doi.org/10.1097/00010694-195209000-00024

[16] Allen, R.G., Pereira, L.S., Raes, D. and Smith, M. (1998) Crop Evapotranspiration-Guidelines for Computing Crop Water Requirements. FAO Irrigation and Drainage Paper No. 56. Food and Agriculture Organization of the United Nations, Rome.

[17] Howell, T.A., Cuenca, R.H. and Solomon, K.H. (1990) Crop Yield Response. In: Hoffman, G.J., Howell, T.A. and Solomon, K.H., Eds., Management of Farm Irrigation Systems, American Society of Agricultural Engineers, St. Joseph, 93-122, 5 fig, 1 tab, 113 ref.

[18] Ampas, V. and Baltas, E. (2009) Optimization of the Furrow Irrigation Efficiency. Global NEST Journal, 11, 566-574. https://doi.org/10.30955/gnj.000529

[19] Ebrahimian, H. and Playán Jubillar, E. (2014) Optimum Management of Furrow Fertigation to Maximize Water and Fertilizer Application Efficiency and Uniformity. Journal of Agricultural Science and Technology, 16, 591-607.

[20] Hiba, G., Latrech, B., Amel, M.B., Douh, B.M., Issam, G. and Boujelben, A. (2019) Using the Step by Step Models to Evaluate Field Application Uniformity of Subsurface Drip Irrigation Systems. Brazilian Journal of Biological Sciences, 6, 233-241. https://doi.org/10.21472/bjbs.061221

[21] Valentín, F., Nortes, P.A., Domínguez, A., Sánchez, J.M., Intrigliolo, D.S., Alarcón, J.J. and López-Urrea, R. (2020) Comparing Evapotranspiration and Yield Performance of Maize under Sprinkler, Superficial and Subsurface Drip Irrigation in a Semi-Arid Environment. Irrigation Science, 38, 105-115. https://doi.org/10.1007/s00271-019-00657-Z

[22] Oker, T.E., Kisekka, I., Sheshukov, A.Y., Aguilar, J. and Rogers, D. (2020) Evaluation of Dynamic Uniformity and Application Efficiency of Mobile Drip Irrigation. Irrigation Science, 38, 17-35. https://doi.org/10.1007/s00271-019-00648-0

[23] Lozano, D., Ruiz, N., Baeza, R., Contreras, J.I. and Gavilán, P. (2020) Effect of Pulse Drip Irrigation Duration on Water Distribution Uniformity. Water, 12, Article No. 2276. https://doi.org/10.3390/w12082276

[24] Sharma, V., Singh, P.K., Bhakar, S.R., Yadav, K.K., Lakhawat, S.S., Sharma, V. and Yadav, S. (2019) Integration of Soil Moisture Sensor Based Automated Drip Irrigation System for Okra Crop. Indian Journal of Pure \& Applied Biosciences, 7, 277-282. https://doi.org/10.18782/2320-7051.7642

[25] Jabro, J.D., Stevens, W.B., Iversen, W.M., Allen, B.L. and Sainju, U.M. (2020) Irrigation Scheduling Based on Wireless Sensors Output and Soil-Water Characteristic Curve in Two Soils. Sensors, 20, Article No. 1336. https://doi.org/10.3390/s20051336

[26] El-Naggar, A.G., Hedley, C.B., Horne, D., Roudier, P. and Clothier, B.E. (2020) Soil Sensing Technology Improves Application of Irrigation Water. Agricultural Water Management, 228, Article ID: 105901. https://doi.org/10.1016/j.agwat.2019.105901

[27] Kandelous, M.M. and Šimůnek, J. (2010) Comparison of Numerical, Analytical, and 
Empirical Models to Estimate Wetting Patterns for Surface and Subsurface Drip Irrigation. Irrigation Science, 28, 435-444. https://doi.org/10.1007/s00271-009-0205-9

[28] Yao, W.W., Ma, X.Y., Li, J. and Parkes, M. (2011) Simulation of Point Source Wetting Pattern of Subsurface Drip Irrigation. Irrigation Science, 29, 331-339. https://doi.org/10.1007/s00271-010-0236-2

[29] Lamm, F.R. and Trooien, T.P. (2005) Dripline Depth Effects on Corn Production When Crop Establishment Is Nonlimiting. Applied Engineering in Agriculture, 21, 835-840. https://doi.org/10.13031/2013.19710

[30] Ma, L., Li, Y., Wu, P., Zhao, X., Chen, X. and Gao, X. (2020) Coupling Evapotranspiration Partitioning with Water Migration to Identify the Water Consumption Characteristics of Wheat and Maize in an Intercropping System. Agricultural and Forest Meteorology, 290, Article ID: 108034. https://doi.org/10.1016/j.agrformet.2020.108034

[31] Leghari, S.J., Hu, K., Wei, Y., Wang, T., Bhutto, T.A. and Buriro, M. (2021) Modelling Water Consumption, N Fates and Maize Yield under Different Water-Saving Management Practices in China and Pakistan. Agricultural Water Management, 255, Article ID: 107033. https://doi.org/10.1016/j.agwat.2021.107033

[32] Irmak, S., Djaman, K. and Rudnick, D.R. (2016) Effect of Full and Limited Irrigation Amount and Frequency on Subsurface Drip-Irrigated Maize Evapotranspiration, Yield, Water Use Efficiency and Yield Response Factors. Irrigation Science, 34, 271-286. https://doi.org/10.1007/s00271-016-0502-Z

[33] Zhang, L., Yan, M., Li, H., Ren, Y., Siddique, K.H., Chen, Y. and Zhang, S. (2020) Effects of Zinc Fertilizer on Maize Yield and Water-Use Efficiency under Different Soil Water Conditions. Field Crops Research, 248, Article ID: 107718. https://doi.org/10.1016/j.fcr.2020.107718

[34] Djaman, K., O’Neill, M., Owen, C.K., Smeal, D., Koudahe, K., West, M., et al. (2018) Crop Evapotranspiration, Irrigation Water Requirement and Water Productivity of Maize from Meteorological Data under Semiarid Climate. Water, 10, Article No. 405. https://doi.org/10.3390/w10040405

[35] Hernandez, M.D., Alfonso, C., Cerrudo, A., Cambareri, M., Della Maggiora, A., Barbieri, P., et al. (2020) Eco-Physiological Processes Underlying Maize Water Use Efficiency Response to Plant Density under Contrasting Water Regimes. Field Crops Research, 254, Article ID: 107844. https://doi.org/10.1016/j.fcr.2020.107844

[36] Mo, Y., Li, G. and Wang, D. (2017) A Sowing Method for Subsurface Drip Irrigation That Increases the Emergence Rate, Yield, and Water Use Efficiency in spring corn. Agricultural Water Management, 179, 288-295.

https://doi.org/10.1016/j.agwat.2016.06.005

[37] Gomaa, M.A., Kandil, E.E., El-Dein, A.A. Z., Abou-Donia, M.E., Ali, H.M. and Abdelsalam, N.R. (2021) Increase Maize Productivity and Water Use Efficiency through Application of Potassium Silicate under Water Stress. Scientific Reports, 11, Article No. 224. https://doi.org/10.1038/s41598-020-80656-9

[38] Shareef, T.M. E., Ma, Z., Chen, J. and Niu, X. (2021) Investigation of the Relationship among Water and Crop Production under Bounded Irrigation Conditions. Computational Water, Energy, and Environmental Engineering, 10, 18-35. https://doi.org/10.4236/cweee.2021.101002 